\title{
Degradation of trichloroethylene by activated persulfate using a reduced graphene oxide supported magnetite nanoparticle
}

Jingchun Yan ${ }^{\mathrm{a}}$, Weiguo Gao ${ }^{\mathrm{a}, \mathrm{b}}$, Mingang Dong ${ }^{\mathrm{c}}, \mathrm{Lu} \mathrm{Han}^{\mathrm{a}, \mathrm{b}}$, Linbo Qian ${ }^{\mathrm{a}}, \mathrm{C}$ Paul Nathanail ${ }^{\mathrm{d}}$, Mengfang Chen ${ }^{\mathrm{a} *}$

${ }^{a}$ Key Laboratory of Soil Environment and Pollution Remediation, Institute of Soil Science, Chinese Academy of Sciences, Nanjing 210008, China

${ }^{\mathrm{b}}$ University of Chinese Academy of Sciences, Beijing 100049, China

${ }^{c}$ Guangdong Provincial Academy of Environmental Science, Guangzhou 510045, China

${ }^{\mathrm{d}}$ University of Nottingham, School of Geography, Nottingham NG7 2RD, UK

\section{Abstract}

A reduced graphene oxide ( $\mathrm{rGO}$ ) supported magnetite nanoparticle $\left(\mathrm{nFe}_{3} \mathrm{O}_{4}\right)$ composite $\left(\mathrm{nFe}_{3} \mathrm{O}_{4} / \mathrm{rGO}\right)$ was synthesized and shown for the first time to be an efficient persulfate activator to generate $\mathrm{SO}_{4}{ }^{-}$for trichloroethylene (TCE) degradation. The degradation efficiency of TCE $\left(0.15 \mathrm{mmol} \mathrm{L}^{-1}\right)$ was $98.6 \%$ within $5 \mathrm{~min}$ in the presence of $6.94 \mathrm{~g} \mathrm{~L}^{-1}$ $\mathrm{nFe}_{3} \mathrm{O}_{4} / \mathrm{rGO}$ with an optimum mass ratio of $1: 4$ and persulfate concentration of $3.0 \mathrm{mmol} \mathrm{L}^{-1}$. By dispersing $\mathrm{nFe}_{3} \mathrm{O}_{4}$ on the rGO surface, nanoparticle agglomeration was prevented and the aggregation of the rGO sheets was disrupted. Both the redox effect coupled in $\mathrm{nFe}_{3} \mathrm{O}_{4}$ and the electron transfer by functional groups containing oxygen on the surface of rGO enhanced the $\mathrm{SO}_{4} \bullet^{-}$generation. Given the identified free radical species and the characterization of the $\mathrm{nFe}_{3} \mathrm{O}_{4} / \mathrm{rGO}$, a persulfate activation mechanism by $\mathrm{nFe}_{3} \mathrm{O}_{4} / \mathrm{rGO}$ for the degradation of TCE

* Corresponding author. Tel: +86 25 86881847; Fax: +86 25 86881126. E-mail: mfchen@issas.ac.cn. 
was interpreted.

Keywords: Reduced graphene oxide, Magnetite nanoparticle, Persulfate, Activation, Trichloroethylene

\section{Introduction}

Chlorinated solvents such as trichloroethylene (TCE) have been frequently detected in groundwater because of their use in industrial processes and for dry-cleaning purposes $[1,2]$. TCE is listed as a priority pollutant by the United States Environmental Protection Agency (USEPA) [3-5], and chronic exposure to TCE via inhalation of vapors released from groundwater may cause cancer and other adverse effects on human health. Various remediation processes such as adsorption, biodegradation, reduction and catalytic oxidation have been employed to remove TCE from groundwater [6,7]. Among these, advanced oxidation processes based on sulfate free radical $\left(\mathrm{SO}_{4}{ }^{-}\right)$have been proposed for the effective degradation and mineralization of TCE [8-10].

Transition metals such as $\mathrm{Fe}(\mathrm{II}), \mathrm{Co}(\mathrm{II}), \mathrm{Mn}(\mathrm{II}), \mathrm{Ce}(\mathrm{II}), \mathrm{Cu}(\mathrm{II})$ and $\mathrm{Ag}(\mathrm{I})$ can be introduced for persulfate $\left(\mathrm{S}_{2} \mathrm{O}_{8}{ }^{2-}\right)$ activation to generate $\mathrm{SO}_{4}{ }^{-}$[11], and homogeneous $\mathrm{Fe}(\mathrm{II})$ is an effective reagent for the production of $\mathrm{SO}_{4}{ }^{-}$in accordance with the following reaction:

$$
\mathrm{Fe}^{2+}+\mathrm{S}_{2} \mathrm{O}_{8}{ }^{2-} \rightarrow \mathrm{Fe}^{3+}+\mathrm{SO}_{4}{ }^{--}+\mathrm{SO}_{4}{ }^{2-}
$$

In a previous study, Liang et al. [12] used the homogeneous $\mathrm{Fe}^{2+} / \mathrm{S}_{2} \mathrm{O}_{8}{ }^{2-}$ system to remediate TCE in solution at $\mathrm{pH} 5.0$, and found that the sulfate radical based system yielded the highest TCE degradation efficiency with a $\mathrm{Fe}^{2+} / \mathrm{S}_{2} \mathrm{O}_{8}{ }^{2-} / \mathrm{TCE}$ molar ratio of 20/15/1. Higher $\mathrm{Fe}^{2+}$ concentrations did not result in more TCE degradation mainly due to the reaction 
between excess $\mathrm{Fe}^{2+}$ and $\mathrm{SO}_{4}{ }^{-}$.

$$
\mathrm{Fe}^{2+}+\mathrm{SO}_{4} \bullet^{-} \rightarrow \mathrm{Fe}^{3+}+\mathrm{SO}_{4}^{2-}
$$

To minimize the competition of $\mathrm{SO}_{4}{ }^{-}$, attempt at using chelating agent of citric acid to manipulate the quantity of $\mathrm{Fe}^{2+}$ in solution was made [13]. Zero valent iron was also introduced as a heterogeneous persulfate activator to control the initial formation rate of $\mathrm{SO}_{4} \bullet^{-}$[14]. In our previous study, magnetite nanoparticle $\left(\mathrm{nFe}_{3} \mathrm{O}_{4}\right)$ were developed as $\mathrm{Fe}(\mathrm{II})$ alternatives to activate persulfate for sulfamonomethoxine degradation [15]. However, due to the strong magnetic interaction and high surface energy, $\mathrm{nFe}_{3} \mathrm{O}_{4}$ particles tend to aggregate thereby partly diminishing their potency for persulfate activation.

Graphene is a promising material and has attracted tremendous attention in recent years. Due to its atom-thick, two-dimensional sheet structure, graphene has a large specific surface area and extraordinary electronic transport. It can therefore immobilize a large number of particles, such as nanoscale zero valent iron, manganese bioxide and iron oxides for environmental application [16-18].

In this study, a reduced graphene oxide (rGO) supported magnetite nanoparticle composite $\left(\mathrm{nFe}_{3} \mathrm{O}_{4} / \mathrm{rGO}\right)$ was synthesized and examined as an efficient persulfate activator for TCE degradation. $\mathrm{nFe}_{3} \mathrm{O}_{4}$ dispersed on $\mathrm{rGO}$ surface would prevent particle agglomeration whilst the superior conductivity of $\mathrm{rGO}$ enables efficient electron transfer between $\mathrm{nFe}_{3} \mathrm{O}_{4}$ and adsorbed hydrophobic pollutants [19]. In addition, the intrinsic atom arrangements of carbon hybridization, pore structure, defective sites, and proper amounts of functional groups (especially the carbonyl groups) of rGO were accounted for persulfate activation to produce radicals [20]. The objectives of this study are to (1) synthesize and characterize a novel 
$\mathrm{nFe}_{3} \mathrm{O}_{4} / \mathrm{rGO}$ composite that prevents aggregation of the magnetite $\mathrm{nFe}_{3} \mathrm{O}_{4}$ particles by precipitating them uniformly onto rGO sheets; (2) to evaluate the persulfate activation potency of the $\mathrm{nFe}_{3} \mathrm{O}_{4} / \mathrm{rGO}$ composite to facilitate degradation of TCE in aqueous solution and (3) to understand the activation mechanism of persulfate in the presence of $\mathrm{nFe}_{3} \mathrm{O}_{4} / \mathrm{rGO}$.

\section{Materials and Methods}

\subsection{Materials}

TCE standard solution $\left(1000 \mu \mathrm{g} \mathrm{mL}^{-1}\right)$ was purchased from Amresco (Solon, OH, USA). $\mathrm{FeSO}_{4} \cdot 7 \mathrm{H}_{2} \mathrm{O}, \mathrm{Fe}\left(\mathrm{NO}_{3}\right)_{3} \cdot 9 \mathrm{H}_{2} \mathrm{O}, \mathrm{H}_{2} \mathrm{O}_{2}, \mathrm{Na}_{2} \mathrm{~S}_{2} \mathrm{O}_{8}, \mathrm{NH}_{3} \cdot \mathrm{H}_{2} \mathrm{O}, \mathrm{NaOH}$ and $\mathrm{KMnO}_{4}$ were obtained from Sinopharm Chemical Reagent Co., Ltd. (Shanghai, China). Graphite powder (SP1) purchased from Bay Carbon (Bay City, MI) was used to prepare rGO. 5,5-Dimethyl-1-Pyrroline-N-Oxide (DMPO) was obtained from Aladdin Industrial Corporation. All the chemicals were of analytical grade and used as received. Deionized water was used in the present work.

\subsection{Preparation of $\mathrm{nFe}_{3} \mathrm{O}_{4} / \mathrm{rGO}$ composite}

Graphene oxide (GO) was prepared from graphite according to a modified Hummers method [21], and rGO was synthesized by reduction of GO using sodium borohydride [22]. $\mathrm{nFe}_{3} \mathrm{O}_{4}$ was prepared through a reverse co-precipitation method using $\mathrm{NH}_{3} \cdot \mathrm{H}_{2} \mathrm{O}$ [15]. The synthesis procedure of $\mathrm{nFe}_{3} \mathrm{O}_{4} / \mathrm{rGO}$ composite was described as follows: $0.10 \mathrm{~g}$ graphene was dispersed in $3.0 \mathrm{~mol} \mathrm{~L}{ }^{-1}$ of $\mathrm{NH}_{3} \cdot \mathrm{H}_{2} \mathrm{O}$ with total volume of $50 \mathrm{~mL}$, then placed in an ultrasound bath $(25 \mathrm{~Hz}, 100 \mathrm{~W}) .0 .12 \mathrm{~g} \mathrm{FeSO}_{4} \cdot 7 \mathrm{H}_{2} \mathrm{O}$ and $0.35 \mathrm{~g} \mathrm{Fe}\left(\mathrm{NO}_{3}\right)_{3} \cdot 9 \mathrm{H}_{2} \mathrm{O}$ were completely dissolved in $10 \mathrm{~mL}$ water and added into the above solution at a rate of $10 \mathrm{~mL}$ $\min ^{-1}$. After $30 \mathrm{~min}$ reaction and cooling to room temperature, the $\mathrm{nFe}_{3} \mathrm{O}_{4} / \mathrm{rGO}$ composites 
were collected by centrifuge, washed with deionized water until $\mathrm{pH}$ was neutral, and then dried under vacuum at $60{ }^{\circ} \mathrm{C}$. The prepared composite was $\mathrm{nFe}_{3} \mathrm{O}_{4} / \mathrm{rGO}$ with a $\mathrm{nFe}_{3} \mathrm{O}_{4}$ to $\mathrm{rGO}$ mass ratio of $1: 1$ as measured by thermogravimetric analysis. $\mathrm{nFe}_{3} \mathrm{O}_{4} / \mathrm{rGO}$ composites with different $\mathrm{nFe}_{3} \mathrm{O}_{4}$ to $\mathrm{rGO}$ mass ratios were also prepared with the above synthesis process.

\subsection{Characterization}

The surface morphology of the materials was characterized using a Hitachi S-4800 scanning electron microscope (SEM) with $15 \mathrm{kV}$ acceleration voltage. The $\mathrm{X}$-ray diffraction (XRD) patterns of $\mathrm{nFe}_{3} \mathrm{O}_{4}, \mathrm{rGO}$ and $\mathrm{nFe}_{3} \mathrm{O}_{4} / \mathrm{rGO}$ composites were determined with a diffractometer (XRD-7000S/L, Shimadzu) with $\mathrm{Cu} \mathrm{K}$ radiation. X-ray photoelectron spectra (XPS) were measured on Axis Ultra spectrometer (Kratos) using a Al Ka radiation excitation source. Fourier transform infrared spectroscopy (FT-IR) was conducted in the range from 400 to $4000 \mathrm{~cm}^{-1}$ to identify the surface functional groups using the Nicolet iS50 (Thermo Fisher Scientific) spectrometer. Raman spectra ranging from 500 to $2500 \mathrm{~cm}^{-1}$ were recorded on a Raman spectrometer (DXR, Thermo Fisher Scientific) with an excitation source of $532 \mathrm{~nm}$, and the Brunauer-Emmett-Teller (BET) specific surface areas $\left(\mathrm{S}_{\mathrm{BET}}\right)$ analysis was performed with a Micromeritics ASAP 2020 accelerated surface area and porosimetry (ASAP) system .

\subsection{Batch Reaction}

Sacrificial batch experiments were carried out in a rotary shaker with $150 \mathrm{rpm}$ at room temperature. Typically for TCE degradation, $0.15 \mathrm{mmol} \mathrm{L}^{-1} \mathrm{TCE}$ and $3.0 \mathrm{mmol} \mathrm{L}{ }^{-1}$ persulfate were in fully filled $20 \mathrm{~mL}$ borosilicate glass. The desired amounts of materials (i.e. $\mathrm{nFe}_{3} \mathrm{O}_{4}$, $\mathrm{rGO}$ and $\mathrm{nFe}_{3} \mathrm{O}_{4} / \mathrm{rGO}$ with different mass ratios) were added, and the glass vials were capped tightly. Control units were also set up under the same conditions with neither activators nor 
persulfate. Solutions in the borosilicate glass were sampled and filtered through membranes for determination at desired time. The concentrations of TCE, dissolved iron and total organic carbon (TOC) were measured, respectively. Sacrificial batches were set up in triplicate, and the mean values were reported.

\subsection{Analytical methods}

The concentrations of TCE were measured by a headspace technique using an Agilent 7890A-5975C Gas Chromatograph-Mass Spectrometer (GC-MS) with a DB-624 (30 m × $0.25 \mathrm{~mm} \times 1.40 \mu \mathrm{m})$ chromatographic column. A 1,10-phenanthrolinemonohydrate spectrophotometry method was introduced to determine dissolved iron in aqueous solution on a Unico UV-2000 spectrophotometer. Total organic carbon (TOC) was calculated with an Analytik Jena AG TOC analyzer. The Electron Spin Resonance (ESR) spectra were received from a $10.00 \mathrm{~mW}$ microwave power Bruker ESR 300E spectrometer.

\section{Results and discussion}

\subsection{Characterization of $\mathrm{nFe}_{3} \mathrm{O}_{4} / \mathrm{rGO}$}

The morphologies of the prepared materials were characterized by SEM. $\mathrm{nFe}_{3} \mathrm{O}_{4}$ particles were spherical with a diameter of about $20 \mathrm{~nm}$ and $\mathrm{rGO}$ had a morphology of crumpled sheet (Fig. 1(a) and (b) respectively). For the $\mathrm{nFe}_{3} \mathrm{O}_{4} / \mathrm{rGO}$ composite, $\mathrm{nFe}_{3} \mathrm{O}_{4}$ was dispersed on the surface of graphene homogeneously (Fig.1(c)). The phase structures of $\mathrm{nFe}_{3} \mathrm{O}_{4}, \mathrm{rGO}$ and $\mathrm{nFe}_{3} \mathrm{O}_{4} / \mathrm{rGO}$ were obtained from XRD spectrum (Fig. 1(d)). The XRD patterns of $\mathrm{Fe}_{3} \mathrm{O}_{4}$ diffraction peaks with $2 \theta$ values of $30.1,35.4,43.1,53.6,57.1$ and $62.7^{\circ}$ were observed. These can be indexed as typical $\mathrm{Fe}_{3} \mathrm{O}_{4}$ diffractions of (220), (311), (400), (422), (511) and (440) respectively (JCPDS 79-0419) [15]. The two representative peaks at 
$2 \theta$ values of 25.1 and $43.0^{\circ}$ were ascribed to (002) and (100) diffraction of rGO sheets [23]. In the XRD spectra of $\mathrm{nFe}_{3} \mathrm{O}_{4} / \mathrm{rGO}$, both the $\mathrm{nFe}_{3} \mathrm{O}_{4}$ and the rGO diffraction peaks were observed, indicating that $\mathrm{nFe}_{3} \mathrm{O}_{4}$ was loaded onto the rGO surface.

Fig. 1(e) shows the Raman spectra of the composites. The D band $\left(1350 \mathrm{~cm}^{-1}\right)$ is ascribed to disordered carbon and the $\mathrm{G}$ band $\left(1596 \mathrm{~cm}^{-1}\right)$ corresponded to $\mathrm{sp}^{2}$ hybridized carbon. The ratio values of $\mathrm{I}_{\mathrm{D}} / \mathrm{I}_{\mathrm{G}}$ for $\mathrm{rGO}$ and $\mathrm{nFe}{ }_{3} \mathrm{O}_{4} / \mathrm{rGO}$ composite were 1.15 and 1.17 respectively, which indicated that the synthesized material was $\mathrm{nFe}_{3} \mathrm{O}_{4} / \mathrm{rGO}$ as anticipated and in accordance with previous research [24]. The FT-IR spectra of $\mathrm{rGO}$ and $\mathrm{nFe}_{3} \mathrm{O}_{4} / \mathrm{rGO}$ are shown in Fig. 1(f). In the rGO spectrum, the peak at $1726 \mathrm{~cm}^{-1}$ is assigned to the $\mathrm{C}=\mathrm{O}$ vibration of $\mathrm{rGO}$ whilst the peak at $1585 \mathrm{~cm}^{-1}$ is assigned to the carbon backbone of the rGO sheets [25]. The signal at $1132 \mathrm{~cm}^{-1}$ indicated the presence of epoxy functional groups, and the peak at $1092 \mathrm{~cm}^{-1}$ corresponds to the deformed $\mathrm{C}-\mathrm{O}$ stretching vibrations [26]. After $\mathrm{nFe}_{3} \mathrm{O}_{4}$ is dispersed on the rGO surface, a new peak appears at $583 \mathrm{~cm}^{-1}$, which can be assigned to the stretching vibration of $\mathrm{Fe}-\mathrm{O}[19]$.

\section{2. $\mathrm{TCE}$ degradation in the $\mathrm{nFe}_{3} \mathrm{O}_{4} /$ graphene-persulfate system}

TCE adsorption onto the prepared materials was tested before examining TCE degradation in the $\mathrm{nFe}_{3} \mathrm{O}_{4} / \mathrm{RGO}$-persulfate system. After shaking for $1 \mathrm{~h}$, equilibrium was established, and the data were shown in Fig. 2(a). TCE removal efficiencies were 5.2\% and $19.7 \%$ with the addition of $1.39 \mathrm{~g} \mathrm{~L}^{-1} \mathrm{nFe}_{3} \mathrm{O}_{4}$ and $5.55 \mathrm{~g} \mathrm{~L}^{-1} \mathrm{rGO}$, respectively. Adding $\mathrm{nFe}_{3} \mathrm{O}_{4} / \mathrm{rGO}$ composite with $\mathrm{nFe}_{3} \mathrm{O}_{4}$ to $\mathrm{rGO}$ mass ratios of $1: 1,1: 2,1: 4$ and 1:6 (with the same concentration of $1.39 \mathrm{~g} \mathrm{~L}^{-1} \mathrm{nFe}_{3} \mathrm{O}_{4}$ ), resulted in TCE removal efficiency of $13.1 \%$, $16.1 \%, 24.6 \%$ and $18.4 \%$, respectively. 
The extent of TCE degradation with persulfate activated by $\mathrm{nFe}_{3} \mathrm{O}_{4}, \mathrm{rGO}$ and various mass ratios of $\mathrm{nFe}_{3} \mathrm{O}_{4} / \mathrm{rGO}$ composites were conducted, and the control tests in the absence of persulfate and activators was also set up which showed less than $2 \%$ TCE loss under the test conditions (curve 1 in Fig. 2(b)). From the data in Fig. 2(b), persulfate alone was unable to significantly degrade TCE in $5 \mathrm{~min}$. Adding $1.39 \mathrm{~g} \mathrm{~L}^{-1} \mathrm{nFe}_{3} \mathrm{O}_{4}$, resulted in TCE degradation efficiency of $48.9 \%$ after 5 min reaction (curve 2 in Fig. 2(b)). Such a low TCE degradation efficiency might be due to aggregation of the $\mathrm{nFe}_{3} \mathrm{O}_{4}$ particles with a relative small $\mathrm{S}_{\mathrm{BET}}$ value of $38.44 \mathrm{~m}^{2} \mathrm{~g}^{-1}$. TCE degradation efficiency of $31.8 \%$ was obtained when $5.55 \mathrm{~g} \mathrm{~L}^{-1}$ graphene was added in the presence of $3.0 \mathrm{mmol} \mathrm{L}^{-1}$ persulfate (curve 3 in Fig. 2(b)). This was slightly higher than $24.6 \%$ by adsorption effect of rGO, suggesting its weak activation ability for persulfate [20]. TCE degradation efficiencies of $67.9 \%, 79.2 \%, 98.6 \%$, and $89.3 \%$ were achieved for the $\mathrm{nFe}_{3} \mathrm{O}_{4} / \mathrm{rGO}$ with mass ratios of $1: 1,1: 2,1: 4$ and $1: 6$, respectively. In comparison with $\mathrm{nFe}_{3} \mathrm{O}_{4}, \mathrm{nFe}_{3} \mathrm{O}_{4} / \mathrm{rGO}$ composite showed better efficiency for persulfate activation. rGO's layer structure gives $\mathrm{S}_{\mathrm{BET}}$ value of $252.09 \mathrm{~m}^{2} \mathrm{~g}^{-1}$, which is lower than the

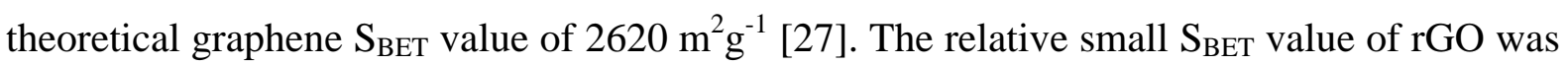
potentially due to the agglomeration of the rGO layers during the reduction process [28]. $\mathrm{nFe}_{3} \mathrm{O}_{4}$ particles were well distributed on the rGO sheet surfaces, which could prevent their aggregation efficiently and disrupting the arrangement of the rGO sheets. Thus, TCE degradation efficiency was enhanced as the rGO mass ratio increased from 1:1 to 1:4 in $\mathrm{nFe}_{3} \mathrm{O}_{4} / \mathrm{rGO}$ composites. However, further increases in $\mathrm{rGO}$ content of $\mathrm{nFe}_{3} \mathrm{O}_{4} / \mathrm{rGO}$ mass ratio from 1:4 to 1:6 might result in an increased aggregation of the rGO sheets, as illustrated from the reduction of their $S_{B E T}$ value from $140.33 \mathrm{~m}^{2} \mathrm{~g}^{-1}$ to $126.72 \mathrm{~m}^{2} \mathrm{~g}^{-1}$. This led to a 
decreased TCE removal efficiency of $89.3 \%$ (curve 7 in Fig. 2(b)). The phenomenon concurs with observations made for a $\mathrm{MnO}_{2} /$ graphene composite used for the catalytic ozonation of gaseous toluene [29].

\subsection{Effects of reaction parameters on the degradation of TCE}

The effects of different concentrations of persulfate and $\mathrm{nFe}_{3} \mathrm{O}_{4} / \mathrm{rGO}$ with a mass ratio of 1:4 on TCE degradation at pH 6.2 are shown in Fig. 2(c) and Fig. 2(d). It can be seen that TCE degradation efficiency increased rapidly from $34.5 \%$ to $84.1 \%$ and a maximum of $98.6 \%$ as persulfate concentration increased from $1.0 \mathrm{mmol} \mathrm{L}^{-1}$ to $2.5 \mathrm{mmol} \mathrm{L}^{-1}$ and $3.0 \mathrm{mmol} \mathrm{L}^{-1}$ respectively with a fixed $\mathrm{nFe}_{3} \mathrm{O}_{4} / \mathrm{rGO}$ concentration of $6.94 \mathrm{~g} \mathrm{~L}^{-1}$. This high TCE degradation efficiency demonstrates the excellent ability of the prepared $\mathrm{nFe}_{3} \mathrm{O}_{4} / \mathrm{rGO}$ composite for persulfate activation.

It has been reported that $\mathrm{SO}_{4}{ }^{-}$was the dominant radical species in $\mathrm{Fe}_{3} \mathrm{O}_{4}$-persulfate system when the solution $\mathrm{pH}$ was less than 7.0 [15]. However, $\bullet \mathrm{OH}$ was preferably produced in the presence of persulfate and $900^{\circ} \mathrm{C}$ heat reduced $\mathrm{rGO}$ [20]. At a persulfate concentration of $3.0 \mathrm{mmol} \mathrm{L}{ }^{-1}$ in aqueous solution, the increase in the amount of $\mathrm{nFe}_{3} \mathrm{O}_{4} / \mathrm{rGO}$ might yield more $\mathrm{SO}_{4}{ }^{-}$and increased TCE degradation efficiency as $\mathrm{nFe}_{3} \mathrm{O}_{4} / \mathrm{rGO}$ concentration increased from 0 to $6.94 \mathrm{~g} \mathrm{~L}^{-1}$ (Fig. 2(d)). However, above $6.94 \mathrm{~g} \mathrm{~L}^{-1} \mathrm{nFe}_{3} \mathrm{O}_{4} / \mathrm{rGO}$, TCE degradation efficiency decreased with increasing $\mathrm{nFe}_{3} \mathrm{O}_{4} / \mathrm{rGO}$ concentration. When $\mathrm{nFe}_{3} \mathrm{O}_{4} / \mathrm{rGO}$ was added in excess of $6.94 \mathrm{~g} \mathrm{~L}^{-1}$, more $\mathrm{SO}_{4} \bullet^{-}$was generated but could not react fully with the TCE. The quenching reaction, according to Eq. (2), between excess Fe(II) on the $\mathrm{nFe}_{3} \mathrm{O}_{4}$ surface and $\mathrm{SO}_{4}{ }^{-}$is rapid and leads to a large amount of $\mathrm{SO}_{4}{ }^{-}$consumption [11]. Moreover, it is reported by Buxton et al. [30] that both scavenging between $\mathrm{SO}_{4}{ }^{-}$species 
themselves and competing interaction between $\mathrm{SO}_{4}{ }^{-}$and persulfate would consume the abundant $\mathrm{SO}_{4}{ }^{-}$in solution (Eq. (3) and Eq. (4)). Hence, the dosage of $\mathrm{nFe}_{3} \mathrm{O}_{4} / \mathrm{rGO}$ was optimized at $6.94 \mathrm{~g} \mathrm{~L}^{-1}$ with $3.0 \mathrm{mmol} \mathrm{L}^{-1}$ persulfate.

$$
\begin{aligned}
& \mathrm{SO}_{4} \bullet^{-}+\mathrm{SO}_{4}{ }^{-} \rightarrow \mathrm{S}_{2} \mathrm{O}_{8}{ }^{2-} \\
& \mathrm{SO}_{4}{ }^{-}+\mathrm{S}_{2} \mathrm{O}_{8}{ }^{2-} \rightarrow \mathrm{SO}_{4}{ }^{2-}+\mathrm{S}_{2} \mathrm{O}_{8}{ }^{-}
\end{aligned}
$$

The effect of $\mathrm{pH}$ on TCE degradation was also investigated in the presence of $\mathrm{nFe}_{3} \mathrm{O}_{4} / \mathrm{rGO}$ and persulfate (Fig. 2(e)). In an acidic solution, additional $\mathrm{SO}_{4^{-}}{ }^{-}$could be formed due to acid catalyzation [31]. Such higher radical concentrations result in increased TCE degradation, and nearly complete TCE degradation efficiency was achieved. Under alkaline conditions, comparatively more $\bullet \mathrm{OH}$ might be formed (cf Eq. (6)). These $\bullet \mathrm{OH}$ would be scavenged by sulfate ions in persulfate oxidation system, and result in a decreased TCE degradation efficiency as $\mathrm{pH}$ increased [32]. The reaction stoichiometric efficiencies (RSE) defined as the number of TCE moles degraded to the number of persulfate moles consumed at a specific time interval $(\Delta[\mathrm{TCE}] / \Delta$ [persulfate] $)$ were calculated at $\mathrm{pH}$ values from 3.0 to 11.0, and the highest RSE for the $\mathrm{pH} 7.0$ was observed (inset in Fig .2(e)). It can be seen from Fig. 2(e) that though TCE degradation efficiency decreased as the solution $\mathrm{pH}$ increased, the efficiency was still $83.1 \%$ at $\mathrm{pH} 9.0$ and $72.0 \%$ at $\mathrm{pH} 11.0$. The relatively low drop in TCE degradation efficiency observed throughout the experimental range of $\mathrm{pH}$ ( $\mathrm{pH}$ of 3.0 to 11.0) indicates that the $\mathrm{nFe}_{3} \mathrm{O}_{4} / \mathrm{rGO}$-persulfate system can remediate polluted water efficiently over a wide range of $\mathrm{pH}$ values.

\subsection{Mineralization and dechlorination of TCE}

To evaluate the mineralization of TCE in the presence of persulfate activated by 
$\mathrm{nFe}_{3} \mathrm{O}_{4} / \mathrm{rGO}$, the TOC removal of TCE was monitored with the TOC analyzer. The complete mineralization of one mole TCE will consume three moles $\mathrm{S}_{2} \mathrm{O}_{8}{ }^{2-}$ in accordance with Eq. (5).

$$
\mathrm{C}_{2} \mathrm{HCl}_{3}+3 \mathrm{~S}_{2} \mathrm{O}_{8}{ }^{2-}+4 \mathrm{H}_{2} \mathrm{O} \rightarrow 2 \mathrm{CO}_{2}+9 \mathrm{H}^{+}+6 \mathrm{SO}_{4}{ }^{2-}+3 \mathrm{Cl}^{-}
$$

In the investigated system of $\mathrm{nFe}_{3} \mathrm{O}_{4} / \mathrm{rGO}$-persulfate, the initial concentration of TCE was $0.15 \mathrm{mmol} \mathrm{L} \mathrm{L}^{-1}$, and the complete mineralization of TCE required $0.45 \mathrm{mmol} \mathrm{L}^{-1} \mathrm{~S}_{2} \mathrm{O}_{8}{ }^{2-}$. It can be seen from Fig. 3(a) that with the addition of $0.45 \mathrm{mmol} \mathrm{L}^{-1} \mathrm{~S}_{2} \mathrm{O}_{8}{ }^{2-}$, the TOC removal after 5 min was only $15.3 \%$, corresponding to the TCE degradation efficiency of $18.8 \%$ by GC-MS results. The low TOC removal was owing to a small amount of $\mathrm{SO}_{4}{ }^{-}$in aqueous solution with low concentration of persulfate. The increase in persulfate concentration to $3.0 \mathrm{mmol} \mathrm{\textrm {L } ^ { - 1 }}$ caused TOC removal efficiency of $54.5 \%$ with TCE degradation efficiency of $98.6 \%$. To enhance TCE mineralization further, $6.0 \mathrm{mmol} \mathrm{L} \mathrm{L}^{-1}$ persulfate was added and resulted in TOC removal of $81.7 \%$, with complete TCE degradation observed in $5 \mathrm{~min}$. The results were in concordance with published data where mineralization extent improved when persulfate concentration is increased in solution [33,34].

For the three different persulfate concentrations used in this study, TCE dechlorination efficiency was also monitored (Fig. 3(b)). When $0.45 \mathrm{mmol} \mathrm{L}^{-1}$ persulfate was added, $\mathrm{Cl}^{-}$but no $\mathrm{ClO}_{3}^{-}$was observed in the solution. After $5 \mathrm{~min}$ reaction, $0.062 \mathrm{mmol} \mathrm{L}^{-1} \mathrm{Cl}^{-}$was detected, accounting for the TCE dechlorination efficiency of $13.7 \%$, which was slightly lower than the TOC removal of $15.3 \%$. When the persulfate concentration increased to 3.0 mmol L ${ }^{-1}, 0.19 \mathrm{mmol} \mathrm{L}^{-1} \mathrm{Cl}^{-}$and $0.023 \mathrm{mmol} \mathrm{L}^{-1} \mathrm{ClO}_{3}{ }^{-}$were detected, indicating a TCE dechlorination efficiency of $47.3 \%$. The appearance of $\mathrm{ClO}_{3}{ }^{-}$was mainly due to the oxidation of $\mathrm{Cl}^{-}$by the generated radicals. For further increase in the persulfate concentration to 6.0 
mmol L ${ }^{-1}, 0.29 \mathrm{mmol} \mathrm{L}^{-1} \mathrm{Cl}^{-}$and $0.042 \mathrm{mmol} \mathrm{L}^{-1} \mathrm{ClO}_{3}^{-}$were measured, and the total amount of $\mathrm{Cl}^{-}$and $\mathrm{ClO}_{3}{ }^{-}$demonstrated a TCE dechlorination efficiency of $73.7 \%$, corresponding to TOC removal of $81.7 \%$ obtained from TOC analyzer.

\subsection{Identification of the free radical species in the $\mathrm{nFe}_{3} \mathrm{O}_{4} / \mathrm{rGO}$-persulfate system}

In the $\mathrm{nFe}_{3} \mathrm{O}_{4} / \mathrm{rGO}$-persulfate system, free radical species are responsible for the degradation and mineralization of organic contaminants due to their high oxidation ability [13]. At different $\mathrm{pH}$ values, two main species of free radicals of $\mathrm{SO}_{4}{ }^{-}$and $\bullet \mathrm{OH}$ may be produced for the activation of persulfate. $\mathrm{SO}_{4}{ }^{-}$can be generated with the decomposition of persulfate and $\bullet \mathrm{OH}$ may be produced with the effect of $\mathrm{OH}^{-}$under alkaline conditions (Eq. (6)). In addition the reaction between $\mathrm{SO}_{4}{ }^{-}$and $\mathrm{H}_{2} \mathrm{O}$, presented in Eq. (7) [34], can also accounted for $\bullet \mathrm{OH}$ generation.

$$
\begin{aligned}
& \mathrm{SO}_{4} \bullet^{-}+\mathrm{OH}^{-} \rightarrow \mathrm{SO}_{4}{ }^{2-}+\cdot \mathrm{OH} \\
& \mathrm{SO}_{4}{ }^{-}+\mathrm{H}_{2} \mathrm{O} \rightarrow \mathrm{SO}_{4}{ }^{2-}+\cdot \mathrm{OH}+\mathrm{H}^{+}
\end{aligned}
$$

To identify the dominant reactive free radical species in the presence of persulfate and $\mathrm{nFe}_{3} \mathrm{O}_{4} / \mathrm{rGO}$ at different $\mathrm{pH}$ values, radical quenching tests were performed. Alcohols with and without $\alpha$-hydrogen, having different rate constants with radical species, were added to the reaction solution. Ethanol (EtOH, containing R-hydrogen) reacts with $\bullet \mathrm{OH}$ and $\mathrm{SO}_{4}{ }^{-}$at high rates: the rate constants are $(1.2 \sim 2.8) \times 10^{9}$ and $(1.6 \sim 7.7) \times 10^{7} \mathrm{~mol} \mathrm{~L}^{-1} \mathrm{~s}^{-1}$ with the reaction of $\mathrm{SO}_{4} \bullet^{-}$and $\bullet \mathrm{OH}$, respectively. Tert-butyl alcohol (TBA, without R-hydrogen) reacts with $\mathrm{SO}_{4} \bullet^{-}$and $\bullet \mathrm{OH}$ at different rates: the rate constant for $\bullet \mathrm{OH}$ is $(3.8 \sim 7.6) \times 10^{8} \mathrm{~mol}$ $\mathrm{L}^{-1} \mathrm{~s}^{-1}$, much greater than $(4 \sim 9.1) \times 10^{5} \mathrm{~mol} \mathrm{~L}^{-1} \mathrm{~s}^{-1}$ for the reaction with $\mathrm{SO}_{4} \bullet^{-}$[35]. Therefore, by adding the EtOH and TBA as quenching agents, the dominant free radicals from the 
activation of persulfate can be clarified.

TCE was completely degraded in 5 min without quenching agents when $\mathrm{pH}$ ranged from 3.0 to 11.0 with addition of $6.0 \mathrm{mmol} \mathrm{L}^{-1}$ of persulfate (curve 1 in Fig. 4). At $\mathrm{pH}$ value of 7.0 as illustrated in Fig. 4, 55.7\% of TCE degradation efficiency and no TCE degradation were observed after the addition of $600.0 \mathrm{mmol} \mathrm{L}^{-1} \mathrm{TBA}$ and $600.0 \mathrm{mmol} \mathrm{L}^{-1} \mathrm{EtOH}$ (molar ratio of quenching agent/persulfate/TCE was 4000/40/1), respectively. The radical quenching effect for TBA was smaller than that for ethanol indicated that $\mathrm{SO}_{4}{ }^{-}-$was the main radical for TCE degradation (An approximate of $55.7 \%$ TCE was degraded by $\mathrm{SO}_{4}{ }^{-}$) $[34,36]$. As pH increased from 9.0 to 11.0 the radical quenching effect of TBA increased, indicating that $\bullet \mathrm{OH}$ was produced, which was responsible for TCE degradation. In addition, the radical quenching effect of TBA at $\mathrm{pH} 11.0$ was greater than that at $\mathrm{pH} 9.0$, suggesting that more $\bullet \mathrm{OH}$ radicals were being generated and played an increasingly significant role during the TCE degradation process.

To obtain direct evidence of the radical species during the activation process, ESR was utilized at different $\mathrm{pH}$ values. The spin trapping agent of DMPO could react with $\mathrm{SO}_{4}{ }^{-}$ or/and $\bullet \mathrm{OH}$ to generate DMPO-SO${ }^{\bullet}{ }^{-}$or/and DMPO- $\bullet \mathrm{OH}$ adduct $\left(a_{\mathrm{H}}=15.6\right.$ and $a_{\mathrm{N}}=14.9$ for DMPO-SO $4^{\bullet}, a_{\mathrm{N}}=13.2 \mathrm{G}, a_{\mathrm{H}}=9.6 \mathrm{G}, a_{\mathrm{H}}=1.48 \mathrm{G}$, and $a_{\mathrm{H}}=0.78 \mathrm{G}$ for DMPO- $\left.\bullet \mathrm{OH}\right)$. The $\mathrm{SO}_{4}{ }^{-}$and $\bullet \mathrm{OH}$ can be identified from the different hyperfine splitting peaks from generated DMPO-SO $4^{\bullet-}$ and DMPO-•OH respectively $[20,37]$. From the results shown in Fig. 5(a), the predominant radical was $\mathrm{SO}_{4} \bullet^{-}$at $\mathrm{pH} 3.0$ and 7.0. At $\mathrm{pH} 9.0$, both $\mathrm{SO}_{4} \bullet^{-}$and $\bullet \mathrm{OH}$ were detected, indicating the generation of $\bullet \mathrm{OH}$ proceeded in accordance with Eq. (6). At $\mathrm{pH}$ 11.0, the reaction for $\bullet \mathrm{OH}$ generation accelerated rapidly, and the dominant signal of $\bullet \mathrm{OH}$ was 
observed in ESR spectra.

\subsection{Activation mechanism of persulfate in presence of $\mathrm{nFe}_{3} \mathrm{O}_{4} / \mathrm{rGO}$}

To explore the activation mechanism of persulfate in the presence of $\mathrm{nFe}_{3} \mathrm{O}_{4} / \mathrm{rGO}$, the dissolved irons $\left(\mathrm{Fe}^{2+}\right.$ and $\left.\mathrm{Fe}^{3+}\right)$ in the presence of $6.94 \mathrm{~g} \mathrm{~L}^{-1} \mathrm{nFe}_{3} \mathrm{O}_{4} / \mathrm{rGO}$ and $3.0 \mathrm{mmol} \mathrm{L}$ persulfate were detected, and $0.04 \mathrm{mmol} \mathrm{L} \mathrm{L}^{-1} \mathrm{Fe}^{2+}$ and $0.17 \mathrm{mmol} \mathrm{L} \mathrm{Fe}^{3+}$ were measured after the reaction (Fig. 2(f)). In comparison with the amount of added iron in $\mathrm{nFe}_{3} \mathrm{O}_{4} / \mathrm{rGO}$ composite, the total dissolved iron could be ignored in the $\mathrm{nFe}_{3} \mathrm{O}_{4} / \mathrm{rGO}$ system, since the molar ratio of dissolved iron to added $\mathrm{nFe}_{3} \mathrm{O}_{4}$ was only $3.5 \%$, and such an amount of dissolved iron only led to $5.0 \%$ TCE degradation in $5 \mathrm{~min}$. Similar to $\mathrm{Fe}^{2+}$ in solution, the surface lattice $\mathrm{Fe}(\mathrm{II})$ of $\mathrm{nFe}_{3} \mathrm{O}_{4}$ may be assumed to have a proper redox potential, and the transformation of $\mathrm{Fe}(\mathrm{II})$ to $\mathrm{Fe}(\mathrm{III})$ can induce the activation of persulfate to generate $\mathrm{SO}_{4}{ }^{-}$.

XPS spectra of $\mathrm{nFe}_{3} \mathrm{O}_{4} / \mathrm{rGO}$ were recorded in order to better understand the roles of $\mathrm{Fe}(\mathrm{II})$ and $\mathrm{Fe}(\mathrm{III})$ species of $\mathrm{Fe}_{3} \mathrm{O}_{4}$ in the activation of persulfate before and after the TCE degradation experiment. As shown in Fig. 5(b), the peaks of Fe(2p) were at 709.9 and 711.2 $\mathrm{eV}$ for the fresh $\mathrm{nFe}_{3} \mathrm{O}_{4} / \mathrm{rGO}$, which were assigned to $\mathrm{Fe}(\mathrm{II})$ and $\mathrm{Fe}(\mathrm{III})$ [38]. Based on the deconvolution of $\mathrm{Fe}(2 \mathrm{p})$ envelope and peak area, the percentages of $\mathrm{Fe}(\mathrm{II})$ and $\mathrm{Fe}(\mathrm{III})$ were $31.3 \%$ and $68.7 \%$ respectively. After 3 times cycle for TCE degradation, the percentage of $\mathrm{Fe}(\mathrm{III})$ increased to $100 \%$, indicating that electron transfer had occurred from $\mathrm{Fe}(\mathrm{II})$ to persulfate on the surface of $\mathrm{Fe}_{3} \mathrm{O}_{4} /$ graphene, accounting for persulfate activation and $\mathrm{Fe}(\mathrm{III})$ generation. In addition, to eliminate signal interferences of graphene, XRD patterns of pure $\mathrm{nFe}_{3} \mathrm{O}_{4}$ instead of $\mathrm{nFe}_{3} \mathrm{O}_{4} / \mathrm{rGO}$ before and after the reaction were examined (Fig. 5(d)). After reaction, a new peak at $22.3^{\circ}$ of used $\mathrm{nFe}_{3} \mathrm{O}_{4}$ appeared, indicating the generation of $\gamma-\mathrm{Fe}_{2} \mathrm{O}_{3}$ 
(JCPDS 4-0755) through the oxidation of $\mathrm{nFe}_{3} \mathrm{O}_{4}$ in the presence of persulfate $[39,40]$. The XRD data also confirmed the transformation of $\mathrm{Fe}(\mathrm{II})$ to $\mathrm{Fe}(\mathrm{III})$ during activation, concurring with the XPS results.

$\mathrm{C}(1 \mathrm{~s})$ spectra of $\mathrm{nFe}_{3} \mathrm{O}_{4} / \mathrm{rGO}$ before and after the reaction were also measured. It can be seen from Fig. 5(c) that $\mathrm{C}-\mathrm{C}(284.5 \mathrm{eV}), \mathrm{C}-\mathrm{OH}(286.5 \mathrm{eV}), \mathrm{C}=\mathrm{O}(288.1 \mathrm{eV})$ and $\mathrm{COOH}$ $(289.0 \mathrm{eV})$ groups were detected, the contents of $54.8 \%, 35.1 \%, 1.1 \%$ and $9.0 \%$ for fresh $\mathrm{nFe}_{3} \mathrm{O}_{4} / \mathrm{rGO}$ [41]. After reaction, the contents of $\mathrm{C}-\mathrm{OH}$ and $\mathrm{COOH}$ groups decreased to $31.7 \%$ and $5.9 \%$, respectively, and no $\mathrm{C}=\mathrm{O}$ group was observed for the used $\mathrm{nFe}_{3} \mathrm{O}_{4} / \mathrm{rGO}$. The decrease of functional groups containing oxygen on the surface of rGO before and after reaction indicated that $\mathrm{rGO}$ is acted as an electron transfer medium during persulfate activation. By proton release, $\mathrm{C}-\mathrm{OH}$ and $\mathrm{COOH}$ groups were transformed to organic radicals of $\mathrm{CO} \bullet$ and $\mathrm{COO} \bullet$, while $\mathrm{SO}_{4}{ }^{-}$and $\mathrm{HSO}_{4}{ }^{-}$were generated after activation [42]. Though $\mathrm{C}=\mathrm{O}$ group of $900^{\circ} \mathrm{C}$ heat reduced $\mathrm{rGO}$ were accounted for $\bullet \mathrm{OH}$ production reported by Duan et al. [20], no obvious $\cdot \mathrm{OH}$ signal was observed in the $\mathrm{nFe}_{3} \mathrm{O}_{4} / \mathrm{rGO}$-persulfate system when $\mathrm{pH}$ values were less than 7.0.

On the basis of the above results, the mechanism of persulfate activation in the presence of $\mathrm{nFe}_{3} \mathrm{O}_{4} / \mathrm{rGO}$ and the TCE degradation process were proposed in Fig. 6. Firstly, $\mathrm{nFe}_{3} \mathrm{O}_{4}$ was well dispersed on the surface of graphene through $\mathrm{Fe}-\mathrm{O}$ bonding, $\mathrm{SO}_{4}{ }^{-}$was then generated from persulfate by the unveiled activation sites of $\mathrm{Fe}(\mathrm{II})$ on $\mathrm{nFe}_{3} \mathrm{O}_{4} / \mathrm{rGO}$ surface. By transferring one electron to persulfate, $\mathrm{Fe}(\mathrm{II})$ was oxidized to $\mathrm{Fe}(\mathrm{III})$, and formed $\gamma-\mathrm{Fe}_{2} \mathrm{O}_{3}$ after activation. Secondly, $\mathrm{C}-\mathrm{OH}$ and $\mathrm{COOH}$ groups on $\mathrm{rGO}$ surface would release organic radicals to produce $\mathrm{SO}_{4}{ }^{-}$, and the electron transferred from rGO to persulfate was 
accelerated via the interface of the hydrophilic moiety of graphene. Once $\mathrm{SO}_{4}{ }^{-}$was produced, it participated in the reaction through electron transfer process to form the TCE radical cation $\left(\mathrm{TCE}^{\bullet}{ }^{+}\right)$that reacted rapidly with $\mathrm{H}_{2} \mathrm{O}$ via hydroxyl abstraction or addition reaction to generate (hydroxyl) TCE radicals $((\mathrm{OH}) \mathrm{TCE} \bullet)$. In addition, if $\mathrm{pH}$ was above 7.0, the generated $\mathrm{SO}_{4}{ }^{-}$would react with $\mathrm{OH}^{-}$to produce $\bullet \mathrm{OH}$, which reacted preferentially with the TCE molecule to generate $(\mathrm{OH}) \mathrm{TCE} \bullet$ through hydrogen abstraction or addition [15]. With the effect of $\mathrm{SO}_{4} \bullet^{-}$and the produced $\bullet \mathrm{OH}$ at $\mathrm{pH}>7.0$, efficient degradation and substantial mineralization of TCE was achieved.

\section{Conclusions}

$\mathrm{nFe}_{3} \mathrm{O}_{4} / \mathrm{rGO}$ was prepared and characterized as a persulfate activator for efficient TCE degradation in aqueous solution. Dispersion of $\mathrm{nFe}_{3} \mathrm{O}_{4}$ on $\mathrm{rGO}$ surface prevented its agglomeration and disrupted rGO sheets arrangement, accounting for TCE degradation efficiency of $98.6 \%$ in $5 \mathrm{~min}$. The redox effect coupled in $\mathrm{nFe}_{3} \mathrm{O}_{4}$ and the electron transfer through functional groups containing oxygen on the surface of rGO promoted the generation of $\mathrm{SO}_{4}{ }^{-}$. The activation of persulfate in the presence of $\mathrm{nFe}_{3} \mathrm{O}_{4} / \mathrm{rGO}$ is shows promise for the remediation of TCE contaminated water.

\section{Acknowledgments}

This work was supported by the National Science Foundation of China (Grants Nos. 51309214 and 41471404), the Science and Technology Service Network Initiative (STS, KFJ-EW-STS-091), the National Environmental Protection Public Welfare Industry Targeted Research Fund (201309005), the National High Technology Research and Development Program (863 Program) (2013AA06A208) and the Natural Science Foundation of Jiangsu 
Province of China (BK2013043).

\section{References}

[1] M.J. Moran, J.S. Zogorki, P.J. Squillance, Chlorinated solvents in groundwater of the United States, Environ. Sci. Technol. 41 (2007) 74-81.

[2] M.N. Goltz, R.K. Gandhi, S.M. Gorelick, G.D. Hopkins, L.H. Smith, B.H. Timmins, P.L. McCarty, Field evaluation of in situ source reduction of trichloroethylene in groundwater using bioenhanced in-well vapor stripping, Environ. Sci. Technol. 39 (2005) 8963-8970.

[3] T. Karanfil, S.A. Dastgheib, Trichloroethylene adsorption by fibrous and granular activated carbons: aqueous phase, gas phase, and water vapor adsorption studies, Environ. Sci. Technol. 38 (2004) 5834-5841.

[4] H.Y. Shin, N. Singhal, J.W. Park, Regeneration of iron for trichloroethylene reduction by Shewanella alga BrY, Chemosphere 68 (2007) 1129-1134.

[5] O. Suttinun, R. Muller, E. Luepromchai, Cometabolic degradation of trichloroethylene by Rhodococcus sp. strain L4 immobilized on plant materials rich in essential oils, Appl. Environ. Microbiol. 76 (2010) 4684-4690.

[6] X. Zhang, X.G. Gu, S.G. Lu, Z.W. Miao, M.H. Xu, X.R. Fu, Z.F. Qiu, Q. Sui, Degradation of trichloroethylene in aqueous solution by calcium peroxide activated with ferrous ion, J. Hazard. Mater. 284 (2015) 253-260. 
[7] A. Banisharif, A.A. Khodadadi, Y. Mortazavi, A.A. Firooz, J. Beheshtian, S. Agah, S. Menbari, Highly active $\mathrm{Fe}_{2} \mathrm{O}_{3}$-doped $\mathrm{TiO}_{2}$ photocatalyst for degradation of trichloroethylene in air under UV and visible light irradiation: Experimental and computational studies, Appl. Catal. B-Environ. 165 (2015) 209-221.

[8] C.J. Liang, C.J. Bruell, M.C. Marley, K.L. Sperry, Thermally activated persulfate oxidation of trichloroethylene (TCE) and 1,1,1-trichloroethane (TCA) in aqueous systems and soil slurries, Soil Sediment Contam. 2003,12 (2), 207-228.

[9] S. Yuan, P. Liao, A.N. Alshawabkeh, Electrolytic manipulation of persulfate reactivity by iron electrodes for trichloroethylene degradation in groundwater, Environ. Sci. Technol. 48 (2014) 656-63.

[10] X.X. Ruan, X.G. Gu, S.G. Lu, Z.F. Qiu, Q. Sui, Trichloroetylene degradation by persulphate with magnetite as a heterogeneous activator in aqueous solution, Environ. Technol. 36 ( 2015) 1389-1397.

[11] G.P. Anipsitakis, D.D. Dionysiou, Radical generation by the interaction of transition metals with common Oxidants, Environ. Sci. Technol. 38 (2004) 3705-3712.

[12] C.J. Liang, C.J. Bruell, M.C. Marley, K.L. Sperry, Persulfate oxidation for in situ remediation of TCE. I. Activated by ferrous ion with and without a persulfate-thiosulfate redox couple, Chemosphere 55 (2004) 1213-1223.

[13] C.J. Liang, C.J. Bruell, M.C. Marley, K.L. Sperry, Persulfate oxidation for in situ remediation of TCE .II. Activated by chelated ferrous ion, Chemosphere 55 (2004) $1225-1233$.

[14] A. Ghauch, G. Ayoub, S. Naim, Degradation of sulfamethoxazole by persulfate assisted micrometric $\mathrm{Fe}^{0}$ in aqueous solution, Chem. Eng. J. 228 (2013) 1168-1181. 
[15] J. Yan, M. Lei, L. Zhu, A.M. Naveed, J. Zou, H. Tang, Degradation of sulfamonomethoxine with $\mathrm{Fe}_{3} \mathrm{O}_{4}$ magnetic nanoparticles as heterogeneous activator of persulfate, J. Hazard. Mater. 186 (2011) 1398-1404.

[16] Y. Wu, H.J. Luo, H. Wang, Removal of para-nitrochlorobenzene from aqueous solution on surfactant-modified nanoscale zero-valent iron/graphene nanocomposites, Environ. Technol. 35 (2014) 2698-2707.

[17] M.C. Hu, K.S. Hui, K.N. Hui, Role of graphene in $\mathrm{MnO}_{2} /$ graphene composite for catalytic ozonation of gaseous toluene, Chem. Eng. J. 254 (2014) 237-244.

[18] J.T. Wang, S.J. Ji, R.Y. Ma, Q.H. Wu, C. Wang, J. Qiang, Z. Wang. Synthesis of magnetic $\mathrm{Fe}_{3} \mathrm{O}_{4}$ modified graphene nanocomposite and its application on the adsorption of some dyes from aqueous solution, Sep. Sci. Technol. 49 (2014) 861-867.

[19] J. Qian, X.W. Yang, L. Jiang, C.D. Zhu, H.P. Mao, K. Wang. Facile preparation of $\mathrm{Fe}_{3} \mathrm{O}_{4}$ nanospheres/reduced graphene oxide nanocomposites with high peroxidase-like activity for sensitive and selective colorimetric detection of acetylcholine, Sensor Actuat B-Chem 201 (2014) 160-166.

[20] X.G. Duan, H.Q. Sun, J. Kang, Y.X. Wang, S. Indrawirawan, S.B. Wang, Insights into heterogeneous catalysis of persulfate activation on dimensional-structured nanocarbons, ACS Catal. 5 (2015) 4629-4636.

[21] W.S. Hummer Jr., R.E. Offeman, Preparation of graphitic oxide, J. Am. Chem. Soc. 80 (1958) 1339-1339.

[22] W. Gao, L.B. Alemany, L.J. Ci, P.M. Ajayan, New insights into the structure and reduction of graphite oxide. Nat. Chem. 1 (2009) 403-408.

[23] X. S. Lv, X.Q. Xue, G.M. Jiang, D.L. Wu, T.T. Sheng, H.Y. Zhou, X.H. Xu. Nanoscale 
Zero-Valent Iron (nZVI) assembled on magnetic $\mathrm{Fe}_{3} \mathrm{O}_{4} /$ graphene for Chromium (VI) removal from aqueous solution. J. Colloid. Interf. Sci. 1 (2014) 51-59.

[24] J. Bai, X. Jiang, A facile One-Pot synthesis of copper sulfide-decorated reduced graphene oxide composites for enhanced detecting of $\mathrm{H}_{2} \mathrm{O}_{2}$ in biological environments, Anal. Chem. 85 (2013) 8095-8101.

[25] R. Xu, H.P. Bi, G.Y. He, J.W. Zhu, H.Q. Chen. Synthesis of Cu-Fe $\mathrm{O}_{4} @$ graphene composite: A magnetically separable and efficient catalyst for the reduction of 4-nitrophenol, Mater. Res. Bull. 57 (2014) 190-196.

[26] M.P. Deosarkar, S.M. Pawar, B.A. Bhanvase, In situ sonochemical synthesis of $\mathrm{Fe}_{3} \mathrm{O}_{4}$-graphene nanocomposite for lithium rechargeable batteries, Chem. Eng. Process. 83 (2014) 49-55.

[27] S. Stankovich, D.A. Dikin, G.H.B. Dommett, K.M. Kohlhaas, E. Zimney, E.A. Stach. Graphene-based composite materials, Nature 442 (2006) 282-286.

[28] B.Z. Jang, A. Zhamu, Processing of nanographene platelets (NGPs) and NGP nanocomposites: a review, J. Mater. Sci. 43 (2008) 5092-5101.

[29] M.C. Hu, K.S. Hui, K.N. Hui, Role of graphene in $\mathrm{MnO}_{2} /$ graphene composite for catalytic ozonation of gaseous toluene, Chem. Eng. J. 254 (2014) 237-244.

[30] G.V. Buxton, C.L. Greenstock, W.P. Helman, A.B. Ross, Critical review of rate constants for reactions of hydrated electrons, hydrogen atoms and hydroxyl radicals $\left(\cdot \mathrm{OH} / \mathrm{O}^{{ }^{-}}\right)$in aqueous solution, J. Phys. Chem. Ref. Data 17 (1998) 513-886.

[31] D.A. House, Kinetics and mechanism of oxidations by peroxydisulfate. Chem. Rev. 62 (1962) 185-203. 
[32] C. Liang, Z.S. Wang, C.J. Bruell, Influence of $\mathrm{pH}$ on persulfate oxidation of TCE at ambient temperatures, Chemosphere 66 (2007) 106-113.

[33] G. Ayoub, A. Ghauch, Assessment of bimetallic and trimetallic iron-based systems for persulfate activation: application to sulfamethoxazole degradation, Chem. Eng. J. 256 (2014) 280-292.

[34]A. Ghauch, A.M. Tuqan, N. Kibbi, Naproxen abatement by thermally activated persulfate in aqueous systems, Chem. Eng. J. 279 (2015) 861-873.

[35] C.J. Liang, H.W. Su, Identification of sulfate and hydroxyl radicals in thermally activated persulfate, Ind. Eng. Chem. Res. 48 (2009) 5558-5562.

[36] A. Ghauch, A.M. Tuqan, N. Kibbi, Ibuprofen removal by heated persulfate in aqueous solution: a kinetics study. Chem. Eng. J. 197 (2012) 483-492.

[37] G.D. Fang, J. Gao, D.D. Dionysiou, C. Liu, D.M. Zhou, Activation of persulfate by quinones: free radical reactions and implication for the degradation of PCBs, Environ. Sci. Technol. 47 (2013) 4605-4611.

[38] L. Lu, Z. Ai, J. Li, Z. Zheng, Q. Li, L. Zhang, Synthesis and characterization of $\mathrm{Fe}-\mathrm{Fe}_{2} \mathrm{O}_{3}$ core-shell nanowires and nanonecklaces, Cryst. Growth Des. 7 (2007) 459-464.

[39] X.X. Ruan, X.G. Gu, S.G. Lu, Z.F. Qiu, Q. Sui, Trichloroethylene degradation by persulphate with magnetite as a heterogeneous activator in aqueous solution, Environ. Technol. 36 (2015) 1389-1397.

[40] Y.S. Zhao, C. Sun, J.Q. Sun, R. Zhou, Kinetic modeling and efficiency of sulfate radical-based oxidation to remove p-nitroaniline from wastewater by persulfate/ $\mathrm{Fe}_{3} \mathrm{O}_{4}$ nanoparticles process, Sep. Purif. Technol. 142 (2015) 182-188. 
[41] J. Huang, Q. Chang, Y. Ding, X. Han, H. Tang, Catalytic oxidative removal of 2,4-dichlorophenol by simultaneous use of horseradish peroxidase and graphene oxide/ $/ \mathrm{Fe}_{3} \mathrm{O}_{4}$ as catalyst, Chem. Eng. J. 254 (2014) 434-442.

[42] F. Niu, J. Wu, L. Zhang, P. Li, J. Zhu, Z. Wu, C. Wang, W. Song, Hydroxyl group rich C60 fullerenol: an excellent hydrogen bond catalyst with superb activity, selectivity, and stability, ACS Catal. 1 (2011) 1158-1161. 


\section{Figures Captions}

Fig. 1. SEM images of (a) $\mathrm{nFe}_{3} \mathrm{O}_{4}$; (b) $\mathrm{rGO}$; (c) $\mathrm{nFe}_{3} \mathrm{O}_{4} / \mathrm{rGO}$; (d) $\mathrm{XRD}$ patterns of $\mathrm{nFe}_{3} \mathrm{O}_{4}, \mathrm{rGO}$ and $\mathrm{nFe}_{3} \mathrm{O}_{4} / \mathrm{rGO}$; (e) Raman spectra of $\mathrm{rGO}$ and $\mathrm{nFe}_{3} \mathrm{O}_{4} / \mathrm{RGO}$ and (f) FT-IR spectra of $\mathrm{rGO}$ and $\mathrm{nFe}_{3} \mathrm{O}_{4} / \mathrm{rGO}$.

Fig. 2. (a) Kinetic adsorption of TCE on (1) $\mathrm{Fe}_{3} \mathrm{O}_{4}$, (2) $\mathrm{rGO}$, (3) $\mathrm{nFe}_{3} \mathrm{O}_{4} / \mathrm{rGO}$ with mass ratio of $1: 1$, (4) $\mathrm{nFe}_{3} \mathrm{O}_{4} / \mathrm{rGO}$ with mass ratio of $1: 2$, (5) $\mathrm{nFe}_{3} \mathrm{O}_{4} / \mathrm{rGO}$ with mass ratio of $1: 4$ and (6) $\mathrm{nFe}_{3} \mathrm{O}_{4} / \mathrm{rGO}$ with mass ratio of 1:6; (b) kinetic data of TCE degradation in the systems of (1) $\mathrm{Na}_{2} \mathrm{~S}_{2} \mathrm{O}_{8}$, (2) $\mathrm{nFe}_{3} \mathrm{O}_{4}-\mathrm{Na}_{2} \mathrm{~S}_{2} \mathrm{O}_{8}$, (3) rGO-Na $\mathrm{Na}_{2} \mathrm{~S}_{2} \mathrm{O}_{8}$, (4) $\mathrm{nFe}{ }_{3} \mathrm{O}_{4} / \mathrm{rGO}$ (mass ratio of 1:1) $-\mathrm{Na}_{2} \mathrm{~S}_{2} \mathrm{O}_{8}$, (5) $\mathrm{nFe}_{3} \mathrm{O}_{4} / \mathrm{rGO}$ (mass ratio of 1:2) $-\mathrm{Na}_{2} \mathrm{~S}_{2} \mathrm{O}_{8}$, (6) $\mathrm{nFe}_{3} \mathrm{O}_{4} / \mathrm{rGO}$ (mass ratio of 1:4) $-\mathrm{Na}_{2} \mathrm{~S}_{2} \mathrm{O}_{8}$ and (7) $\mathrm{nFe}_{3} \mathrm{O}_{4} / \mathrm{rGO}$ (mass ratio of 1:6) $-\mathrm{Na}_{2} \mathrm{~S}_{2} \mathrm{O}_{8}$; (c) effect of persulfate concentration on TCE degradation; (d) effect of $\mathrm{nFe}_{3} \mathrm{O}_{4} / \mathrm{rGO}$ concentration on TCE degradation; (e) influence of initial solution $\mathrm{pH}$ on TCE degradation. (1) Square symbols represent TCE removal and (2) circles represent persulfate consumption; and (f) iron concentration in aqueous solution (1) before and (b) after reaction. Reaction conditions: the concentration of $\mathrm{nFe}_{3} \mathrm{O}_{4}$ itself or in $\mathrm{nFe}_{3} \mathrm{O}_{4} / \mathrm{rGO}$ composite was $1.39 \mathrm{~g} \mathrm{~L}^{-1}$, the concentration of $\mathrm{rGO}$ was $5.55 \mathrm{~g} \mathrm{~L}^{-1}$, the concentration of $\mathrm{Na}_{2} \mathrm{~S}_{2} \mathrm{O}_{8}$ was $3.0 \mathrm{mmol} \mathrm{L}^{-1}$, the concentration of TCE was $0.15 \mathrm{mmol} \mathrm{L}^{-1}$, and the initial $\mathrm{pH}$ was 6.2 .

Fig. 3. (a) Removal of TOC and (b) release of $\mathrm{Cl}^{-}$and $\mathrm{ClO}_{3}{ }^{-}$in the presence of (1) $0.45 \mathrm{mmol} \mathrm{L}^{-1}$, (2) 3.0 mmol L $\mathrm{L}^{-1}$ and (3) $6.0 \mathrm{mmol} \mathrm{L}^{-1}$ persulfate during the degradation of TCE in the $\mathrm{nFe}_{3} \mathrm{O}_{4} / \mathrm{rGO}$-persulfate systems.

Fig. 4. TCE degradation (1) without EtOH and TBA, (2) with $600.0 \mathrm{mmol} \mathrm{L}^{-1} \mathrm{TBA}$ and (3) with 600.0 mmol L-1 EtOH in the presence of $\mathrm{nFe}_{3} \mathrm{O}_{4} / \mathrm{rGO}$ and $\mathrm{Na}_{2} \mathrm{~S}_{2} \mathrm{O}_{8}$ under different initial $\mathrm{pH}$ values within 5 min. Reaction conditions: the concentration of $\mathrm{nFe}_{3} \mathrm{O}_{4} / \mathrm{rGO}$ was $13.88 \mathrm{~g} \mathrm{~L}^{-1}$, the concentration of $\mathrm{Na}_{2} \mathrm{~S}_{2} \mathrm{O}_{8}$ was $6.0 \mathrm{mmol} \mathrm{L}^{-1}$ and the concentration of TCE was $0.15 \mathrm{mmol} \mathrm{L}^{-1}$.

Fig. 5. (a) DMPO spin-trapping ESR spectra of $\mathrm{SO}_{4}{ }^{\bullet} / \cdot \mathrm{OH}$ radicals in the systems of $\mathrm{nFe}_{3} \mathrm{O}_{4} / \mathrm{rGO}$ (mass 
ratio of 1:4)- $\mathrm{Na}_{2} \mathrm{~S}_{2} \mathrm{O}_{8}$-TCE at different $\mathrm{pH}$ values; (b) $\mathrm{Fe} 2 \mathrm{p}$ XPS spectra of $\mathrm{nFe}_{3} \mathrm{O}_{4} / \mathrm{rGO}$ before and after the reaction; (c) C 1s XPS spectra of $\mathrm{nFe}_{3} \mathrm{O}_{4} / \mathrm{rGO}$ before and after the reaction and (d) XRD patterns of $\mathrm{nFe}_{3} \mathrm{O}_{4}$ before and after reaction.

Fig. 6. A proposed mechanism for the degradation of $\mathrm{TCE}$ by $\mathrm{nFe}_{3} \mathrm{O}_{4} / \mathrm{rGO}$ activation of persulfate. 

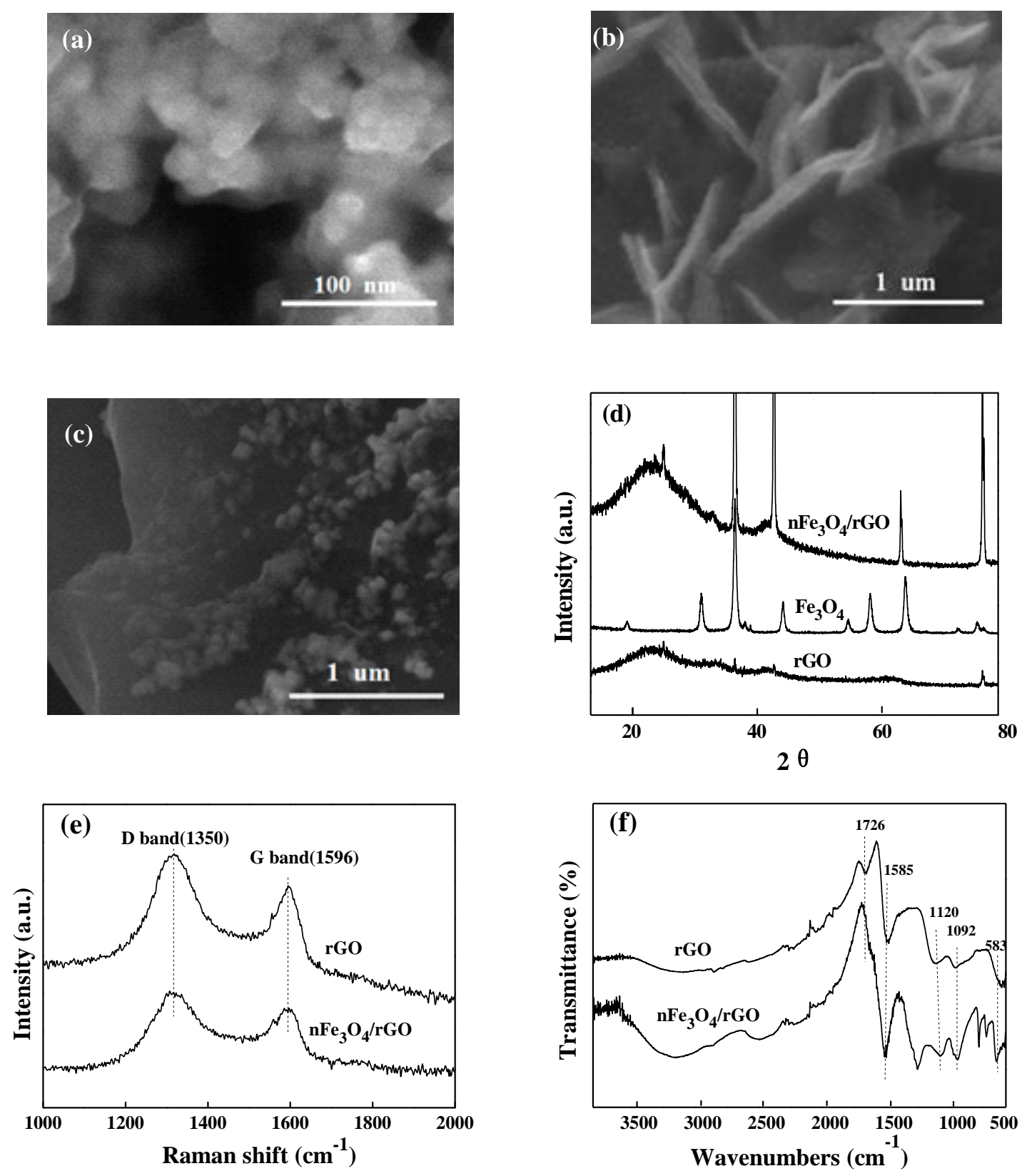

Fig. 1 

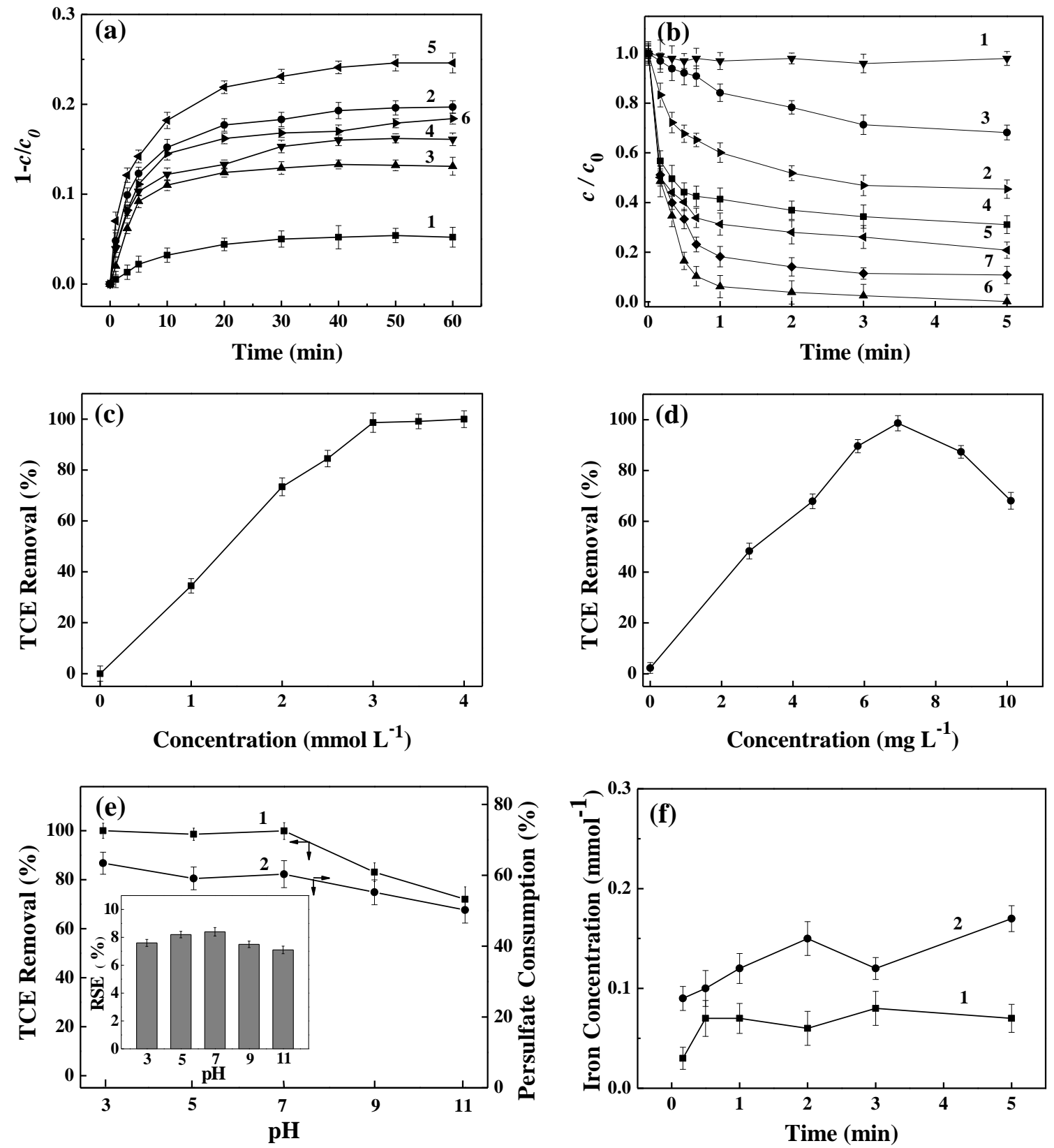

Fig. 2 

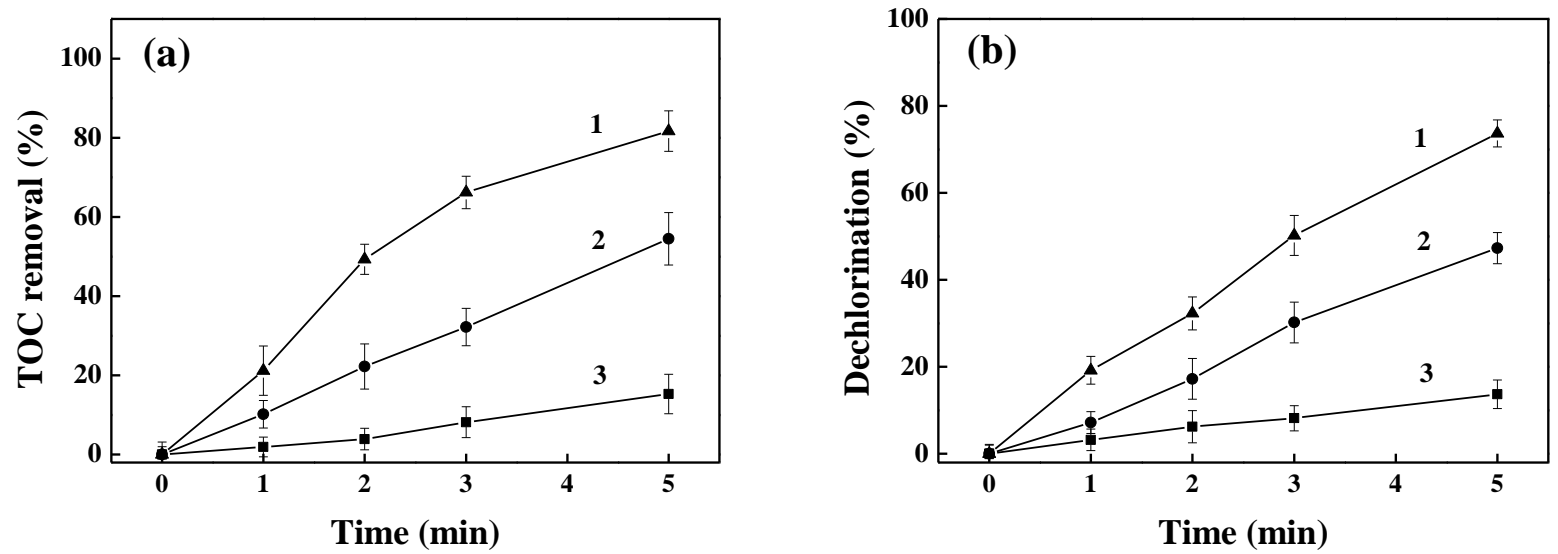

Fig. 3 


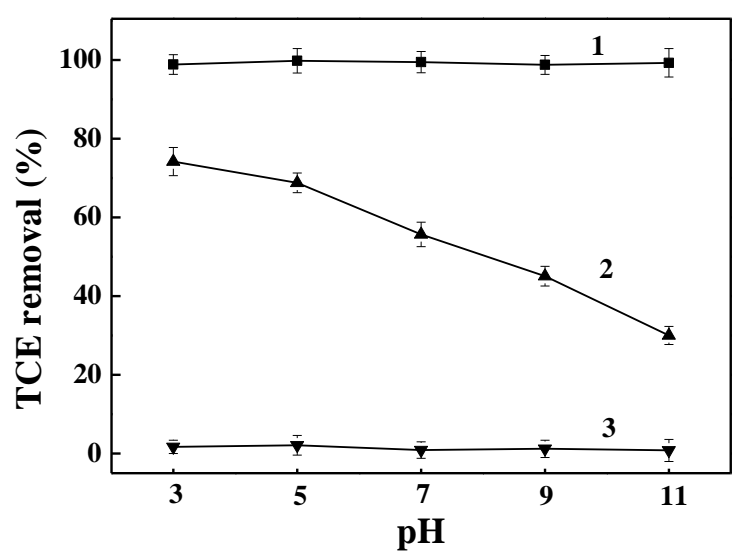

Fig.4 

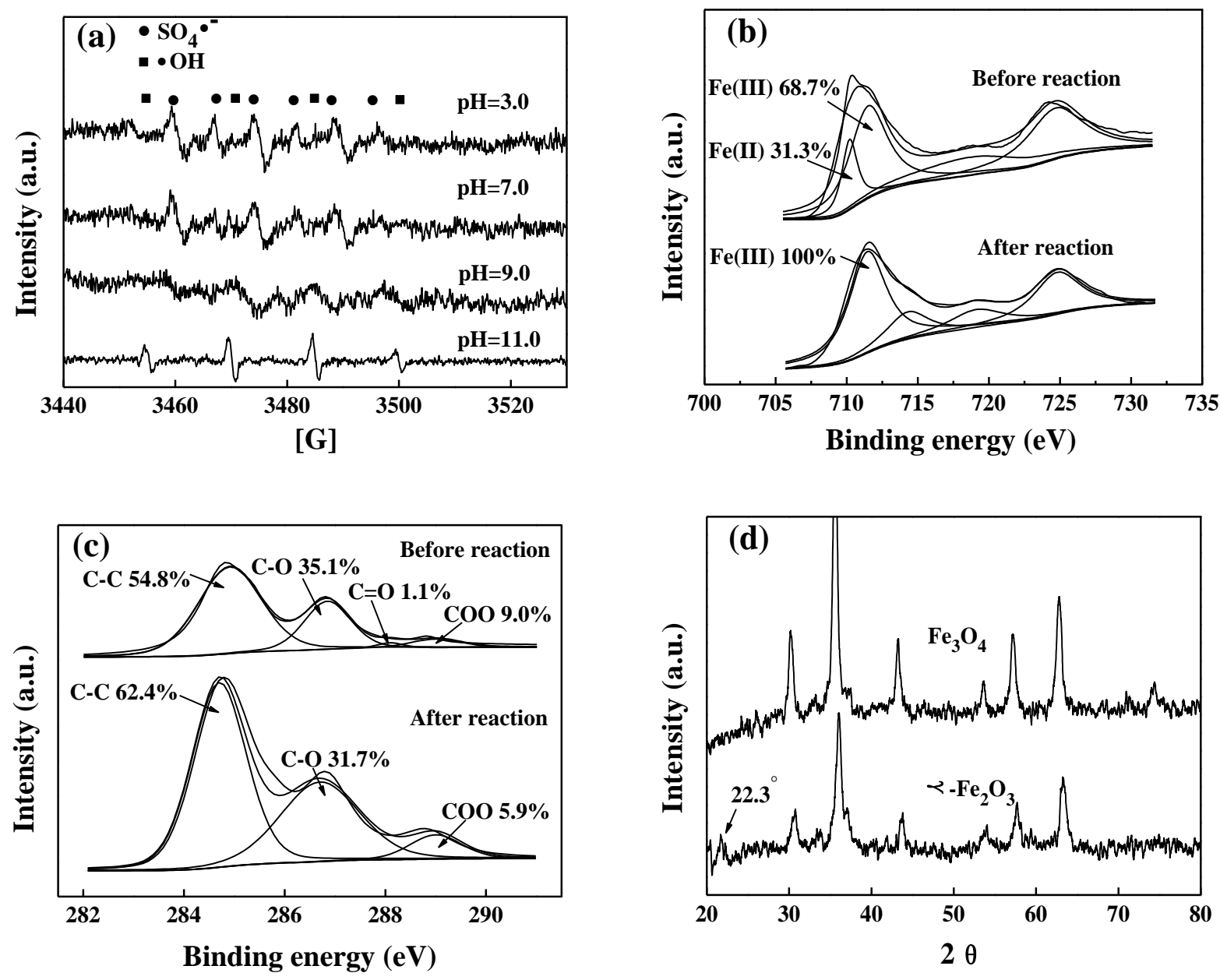

Fig. 5 


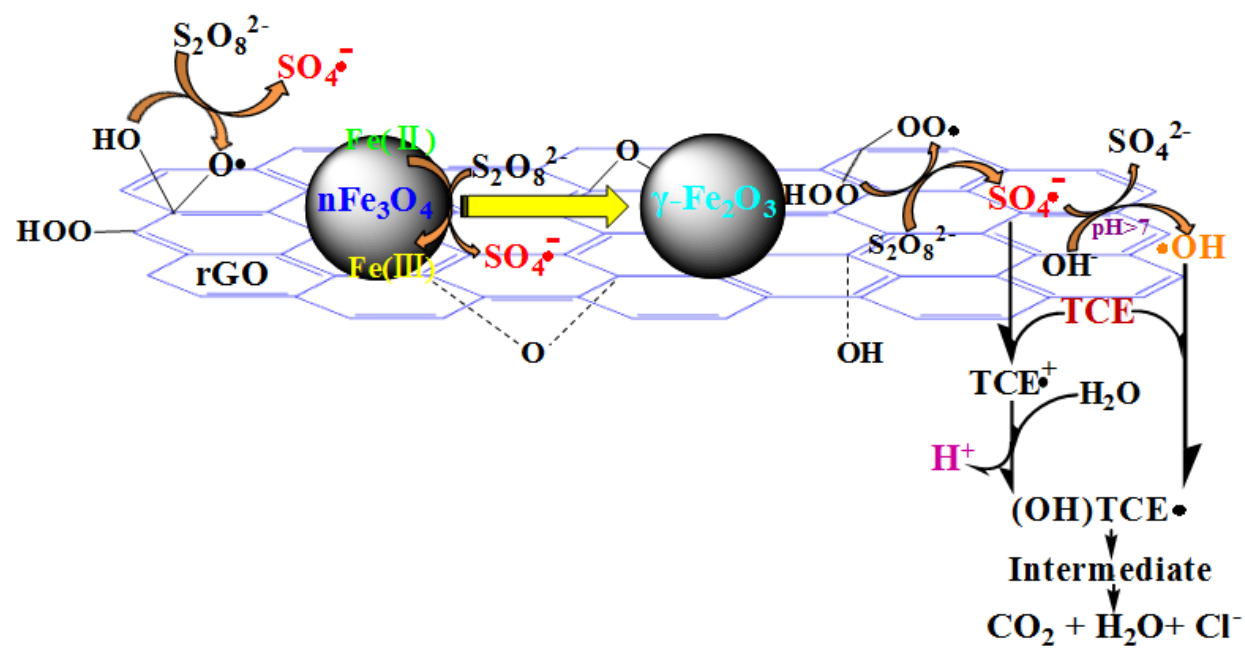

Fig. 6 


\section{Graphical abstract}

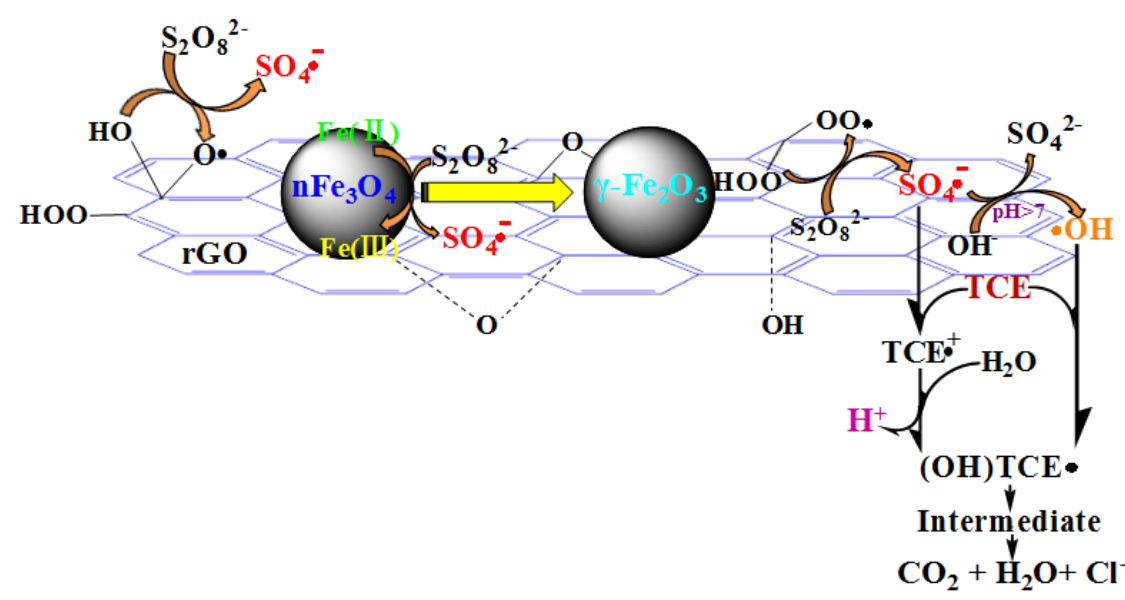

